\title{
Removal of Tricyclazole and Total Organic Carbon in Real Pesticide Wastewater by Electro-Fenton
}

\author{
Ha Manh Bui $\mathbb{D}^{1}$ and Loan Ngoc Huynh $\mathbb{D}^{2}$ \\ ${ }^{1}$ Department of Environmental Sciences, Saigon University, 273 An Duong Vuong Street, District 5, \\ Ho Chi Minh City 70000, Vietnam \\ ${ }^{2}$ Institute for Environment and Resources, Vietnam National University of Ho Chi Minh City, Thu Duc City, \\ Ho Chi Minh City 70000, Vietnam \\ Correspondence should be addressed to Ha Manh Bui; manhhakg@yahoo.com.vn
}

Received 4 June 2021; Accepted 18 August 2021; Published 19 January 2022

Academic Editor: Ibrahim H. Alsohaimi

Copyright (c) 2022 Ha Manh Bui and Loan Ngoc Huynh. This is an open access article distributed under the Creative Commons Attribution License, which permits unrestricted use, distribution, and reproduction in any medium, provided the original work is properly cited.

\begin{abstract}
In this study, electro-Fenton (EF) was employed for the removal of tricyclazole (TC) and total organic carbon (TOC) in real pesticide wastewater (RPW). The central composite design (CCD) with three parameters, that is, current density, $\mathrm{Fe}^{2+}$ concentration, and electrolysis time, has been conducted to predict the TOC and TC removal efficiency. The high correlation of the quadratic models of 0.9842 and 0.9781 for TC and TOC removal, respectively, indicates the significance of the models. The obtained results revealed that the high-efficiency removal of both TC and TOC in RPW. Approximately $99.6 \%$ of TC was decomposed under the optimum conditions of a current density of $2.2 \mathrm{~mA} / \mathrm{cm}^{2}$ and an $\mathrm{Fe}^{2+}$ concentration of $0.2 \mathrm{mM}$ during $188 \mathrm{~min}$ with an operating cost of $121.392 \$ / \mathrm{kg}$ TC or $\sim 2.692 \$ / \mathrm{m}^{3}$, while $84.2 \%$ TOC was eliminated at a current density of $2.2 \mathrm{~mA} / \mathrm{cm}^{2}$ and an $\mathrm{Fe}^{2+}$ concentration of $0.2 \mathrm{mM}$ during $217 \mathrm{~min}$ with an operating cost of $3.019 \$ / \mathrm{kg}$ TOC or $3.916 \$ / \mathrm{m}^{3}$. Acute toxicity tests at optimal condition revealed moderate exhibition toxicity of treated wastewater against Daphnia magna with $\mathrm{LC}_{50}$ values of $3.12 \%, 2.05 \%, 1.84 \%$, and $1.36 \%$ at $24 \mathrm{~h}, 48 \mathrm{~h}, 72 \mathrm{~h}$, and $96 \mathrm{~h}$, respectively. The removal of TC and TOC followed pseudofirst-order kinetic with an $R^{2}$ of $\sim 0.993$ and 0.923 , respectively.
\end{abstract}

\section{Introduction}

Agriculture is critical to the economies of Vietnam, in which export-oriented agricultural production is a significant source of foreign exchange earnings. The agricultural sector provides approximately $14.85 \%$ of the gross national product with over 18.8 million Vietnamese in 2019 [1]. However, the vast number of pesticides produced to prevent pests or diseases on crops resulting in threats to the environment and human health [2]. Extensive studies have reported that pesticides originating from agriculture factories are characterized by a high chemical oxygen demand (COD), total suspended solids (TSS), and toxicity. In particular, pesticide application to rice paddies has been detected in surface water, groundwater, and soil [3]. These kinds of pesticides also stand out in high production and worldwide distribution; tricyclazole (TC) is a unique fungicide among the most widely used pesticides for control of Pyricularia oryzae in rice fields $[4,5]$. Duy et al. [6] stated that TC was moderately toxic to tropical freshwater Daphnia species $\left(48 \mathrm{~h} \mathrm{LC}_{50}, 32.68 \mathrm{mg} / \mathrm{L}\right)$. Werner et al. [7] also stated that TC could display human mutagenic and carcinogenic [8]. Therefore, it is necessary to use appropriate techniques to remove these pollutants to preserve the environment from contaminated water. Biological processes are quite economical for the treatment of wastewaters. Wu et al. [8] had isolated Sphingomonas sp. NJUST37 from activated sludge and successfully applied to degrade over $90 \%$ tricyclazole in pilot-scale powdered activated carbon treatment tank after 81 days. However, the COD is still high around $160 \mathrm{mg} / \mathrm{L}$, and further treatment time has insignificant effect on the removal efficiency. Moreover, biological methods have 
proven ineffective in removing refractory or nonbiodegradable compounds [9]. For instance, biological treatment processes have not successfully removed pesticide wastewater [10]. Alternatively, physicochemical techniques, that is, coagulation, adsorption, nanofiltration, and so on, are also used to treat wastewater; Azarkan et al. [11] had collected four clays with different characteristics from various locations in northern Morocco to adsorb $5 \mathrm{mg} / \mathrm{L}$ TC from solution; the TC mitigation obeyed pseudo-second-order kinetic model with $R^{2}$ values $\geq 0.95$. However, the TC removal efficiency only reached from 0.27 to $28.59 \%$ for the clays. While Kiso et al. [12] indicated that $79.8 \%$ of TC were removed using nanomembrane; the authors also stated that three other nanomembranes were negligible on the rejection of TC. Even though these methods have some applications in TC removal, these techniques transfer only the pollution from one phase to another, requiring further treatment $[9,13]$. Therefore, it is essential to develop more effective treatment methods to eradicate the contaminants.

For instance, advanced oxidation processes (AOPs) are proven to be the most effective techniques for the degradation of a wide range of pollutants in aqueous solutions such as pharmaceutical $[14,15]$, pesticide [6], dyeing, and textile $[16,17]$. The process is characterized by their ability to generate hydroxyl radical $\left({ }^{\circ} \mathrm{OH}\right)$ and other reactive oxygen species. One of the most important chemical reactions in the advanced oxidation process is Fenton $\left(\mathrm{Fe}^{2+/} \mathrm{H}_{2} \mathrm{O}_{2}\right)$ and Fenton-like systems. The Fenton reaction was the first described by H. J. H. Fenton in 1894 [18] with chemical mechanism according to the following equation:

$$
\mathrm{Fe}^{+2}+\mathrm{H}_{2} \mathrm{O}_{2} \longrightarrow \mathrm{Fe}^{3+}+\cdot \mathrm{OH}+\mathrm{OH}^{-} .
$$

The Fenton reaction consists of reducing $\mathrm{H}_{2} \mathrm{O}_{2}$ until hydroxyl radicals and hydroxide caused by oxidation of $\mathrm{Fe}^{2+}$ to $\mathrm{Fe}^{3+}$.

However, this method has drawbacks related to the wastage of oxidants (iron ions or $\mathrm{H}_{2} \mathrm{O}_{2}$ ) and the formation of excess sludge [19]. The new Fenton process based on electrolysis systems has been developed and called electroFenton (EF) to overcome the disadvantages of homogeneous Fenton. In the EF process, $\mathrm{H}_{2} \mathrm{O}_{2}$ can be generated at the cathode when bubbling oxygen gas through the acidic solution, followed by reducing $\mathrm{H}_{2} \mathrm{O}_{2}$. The electrochemical generation of $\mathrm{Fe}^{2+}$ ions occurs through the reaction of anodic material dissolution or cathodic reduction of $\mathrm{Fe}^{3+}$ ions [18]. In this process, pollutants are destroyed by Fenton's action reagent together with the combination of anode oxidation on the anode surface. The Fenton process and electrochemical are combined with the increasing degradability of organic compounds present in high-intensity wastes. Even several researchers have applied EF to eliminate pollutants from wastewater of dyeing and textile [20, 21], pharmaceuticals [14], coke [22], pesticides [23-25], or mixed industrial wastewater [26]. Very few studies focus on the mineralization and biodegradability of tricyclazole and pollutants from real pesticide production by $\mathrm{EF}$ process [27].
In the present work, the degradation of TC and total organic carbon (TOC) in real pesticide production wastewater are investigated using the $\mathrm{EF}$ process in a batch chemical reactor. This study aims to analyze how the degradation process of TC and TOC can be affected by current density, $\mathrm{Fe}^{2+}$ dosage, and electrolysis time using a central composite design (CCD). Additionally, the degradation mechanism is investigated based on kinetics studies, the toxicity of the wastewater on Daphnia magna, and operating costs.

\section{Experimental}

2.1. Chemical and Real Pesticide Wastewater (RPW). Ferrous sulfate $\left(\mathrm{FeSO}_{4}\right)$, sodium hydroxide $(\mathrm{NaOH})$, sodium sulfate $\left(\mathrm{Na}_{2} \mathrm{SO}_{4}\right)$, hydrogen chloride $(\mathrm{HCl})$, and sulfuric acid $\left(\mathrm{H}_{2} \mathrm{SO}_{4}\right)$ were purchased from Xilong Scientific Corporation Ltd., China. All the chemicals were of analytical grade, and solutions were prepared with deionized water of resistivity not less than $18.2 \mathrm{M} \Omega / \mathrm{cm}$. The pesticide effluent was obtained from an agriculture production company located in Longan province, Vietnam. It was collected in an equalization tank after a sieve system. Wastewater was collected in a glass container and preserved at $4^{\circ} \mathrm{C}$ for treatment by $\mathrm{EF}$. The effluent characteristics are as follows: initial $\mathrm{pH}$ of 6.6-7.2, total organic carbon (TOC) of $1,236-1,358 \mathrm{mg} / \mathrm{L}$, tricyclazole (TC) of $23.7-25.1 \mathrm{mg} / \mathrm{L}$, and total nitrogen (TN) of $240-272 \mathrm{mg} / \mathrm{L}$.

2.2. Acute Toxicity Assay. After treatment, the pesticide wastewater with the optimal condition for TOC was selected to test the toxicity to D. magna.

The effluent was characterized as $\mathrm{pH}$ of 6.8 , total organic carbon (TOC) of $204.4 \mathrm{mg} / \mathrm{L}$, tricyclazole (TC) of $0.185 \mathrm{mg} /$ $\mathrm{L}$, and total nitrogen (TN) of $72.6 \mathrm{mg} / \mathrm{L}$. D. magna obtained from MicroBioTest Inc., Belgium, was used for the test. The acute test was performed according to the OECD guideline 202 [28]. D. magna live stocks were cultured in glass containers at a density of 1 individual $/ 10 \mathrm{~mL}$ of ISO medium [29]. The test organisms were daily fed a mixture of Scenedesmus sp. and Chlorella sp. The culture medium was renewed every three days and maintained at $25 \pm 1^{\circ} \mathrm{C}$ under a 12:12 h light-dark cycle. For each test samples, a serial dilution $(0.1 \%, 0.25 \%, 0.5 \%, 1.0 \%, 2 \%$, and $5 \%)$ of PWAT plus the blank control was used. All test concentrations were prepared in triplicate and spiked with $40 \mathrm{~mL}$ of ISO medium in $50 \mathrm{~mL}$ glass beakers. Ten neonates $(<24 \mathrm{~h}$ old) were added to each beaker. The test was run for $96 \mathrm{~h}$ at a stable $\mathrm{pH}$ and temperature 7.5 and $25 \pm 1^{\circ} \mathrm{C}$, respectively. The mortality of tested neonates was checked at $24 \mathrm{~h}, 48 \mathrm{~h}, 72 \mathrm{~h}$, and $96 \mathrm{~h}$. The median lethal concentrations $\left(\mathrm{LC}_{50}\right)$ at $24 \mathrm{~h}, 48 \mathrm{~h}, 72 \mathrm{~h}$, and $96 \mathrm{~h}$ were calculated using Probit analysis.

2.3. Experimental Procedures. The reactor used for the treatment was made of glass with the dimensions of $160 \times 160 \times 250 \mathrm{~mm}$ totalizing a volume of $3 \mathrm{~L}$ of effluent per treatment (Figure 1). The experiments were performed in a bipolar batch reactor, with two iron electrodes anode (Fe: 


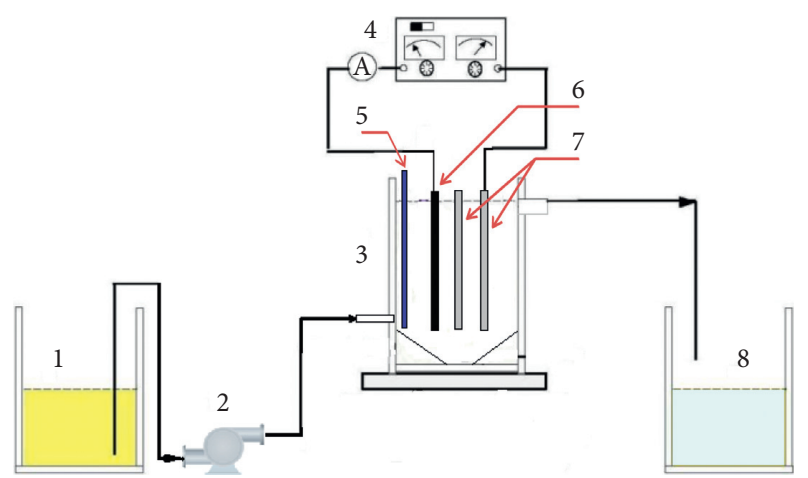

Figure 1: Schematic diagram of electro-Fenton experimental system: (1) feed tank, (2) pump, (3) EF reactor, (4) DC power supply, (5) feed air, (6) carbon-plated iron, (7) iron-plated tank, and (8) product tank.

99.25\% $-\mathrm{CT}_{2}$ ) and carbon plated iron cathode, dimensions of $146 \times 150 \times 4 \mathrm{~mm}$ connected in parallel. Only the outer electrodes were connected to the digital DC power supply (QJ3003XE, 30V-3A). While the air flow rate was fixed at $3 \mathrm{~L} / \mathrm{min}$ [30], the electric current applied in the treatments was ranged from 1.11 to $3.33 \mathrm{~mA} / \mathrm{cm}^{2}$. For better electron conductivity in the effluent, $990 \mathrm{mg} / \mathrm{L}$ of $\mathrm{Na}_{2} \mathrm{SO}_{4}$ was added to each treatment. Furthermore, to avoid electrode passivation, at the end of each run, the electrodes were washed thoroughly with water and dipped in $0.5 \mathrm{M} \mathrm{H}_{2} \mathrm{SO}_{4}$ solution for at least $15 \mathrm{~min}$ to dissolve any oxide from the electrode surface All trials were performed at room temperature of 20 to $25^{\circ} \mathrm{C}\left( \pm 1.0^{\circ} \mathrm{C}\right)$ and adjusted initial $\mathrm{pH}$ from 2.8 to $3.2 \mathrm{using}$ $\mathrm{H}_{2} \mathrm{SO}_{4}(0.2 \mathrm{M})$ before conducting the experiments.

2.4. Experimental Design. Screening experiments with fixed current density of $2.22 \mathrm{~mA} / \mathrm{cm}^{2}$ and $0.2 \mathrm{mM}$ of Fe${ }^{2+}$ dosage for $180 \mathrm{~min}$ were conducted to determine kinetic reaction and also investigate the effect of these factors on TC and TOC removal efficiency. Then the central composite design (CCD) was then carried out to determine the optimal condition for TOC and TC removal during the EF process. Three independent variables were applied: current density $\left(X_{1}\right), \mathrm{Fe}^{2+}$ dosage $\left(X_{2}\right)$, and electrolysis time $\left(X_{3}\right)$. The level of each code ranged from low $(-1)$ to high (1), as shown in Table 1 based on our previous screening experiments.

Twenty experimental sets were designed, including eight sets from $2 \mathrm{k}$ of a factorial point, six sets from $2 \mathrm{k}$ of the axial point, and six sets from the central point (Table 2), where $k$ is the number of independent variables factors [31]. The TC and TOC removal efficiencies, calculated by the following equation, were defined as the dependent variable's response.

$$
\text { Removal efficiency }(\%)=\frac{\left(C_{0}-C_{i}\right)}{C_{0}} \times 100,
$$

where $C_{0}$ is the concentration of TC or TOC at the initial time and $C_{i}$ is the concentration of TC or TOC at any time $t$ of electrolysis.

The mathematics model was evaluated using Minitab version 18.1 software and expressed in a quadratic model
TABLE 1: Factors and their levels used for experiments by the CCD.

\begin{tabular}{lcccccc}
\hline & & \multicolumn{5}{c}{ Level } \\
Parameters & Symbol & \multicolumn{2}{c}{ Low } & Center & \multicolumn{2}{c}{ High } \\
& & $-\alpha$ & -1 & 0 & 1 & $+\alpha$ \\
\hline Current density (mA/ & $X_{1}$ & 0.35 & 1.11 & 2.22 & 3.33 & 4.09 \\
$\left.\mathrm{~cm}^{2}\right)$ & $X_{2}$ & 0.03 & 0.1 & 0.2 & 0.3 & 0.37 \\
$\mathrm{Fe}^{2+}$ dosage (mM) & $X_{3}$ & 129 & 150 & 180 & 210 & 230 \\
Electrolysis time (min)
\end{tabular}

equation as follows. The least-square regression calculated the coefficient. The $\beta_{0}, \beta_{i}, \beta_{i}, \beta_{i j}$, and $e$ are the constant coefficient, linear coefficient, quadratic coefficient, interaction coefficient, and statistical error, respectively. The adequacy and significance of the model were justified by the analysis of variance (ANOVA).

$$
Y=\beta_{0}+\sum_{i=1}^{k} \beta_{i} X_{i}+\sum_{i=1}^{k} \beta_{i i} X_{i}^{2}+\sum_{i=1}^{k-1} \sum_{j=2}^{k} \beta_{i j} X_{i} X_{j}+e .
$$

To verify the model accuracy, three confirmed experiments were also conducted at optimal condition (current density of $2.2 \mathrm{~mA} / \mathrm{cm}^{2}$, the $\mathrm{Fe}^{2+}$ dosage of $0.25 \mathrm{mM}$, and electrolysis time of $217 \mathrm{~min}$ ).

2.5. Analysis Method and Energy Consumption. All assays were performed at room temperature $\left(20\right.$ to $\left.25^{\circ} \mathrm{C}\right)$, and the treated samples were collected, filtered, and analyzed for total nitrogen (TN) and total organic carbon (TOC), using TOC VCPH/CPN instrument (SHIMADZU, Japan). TC was analyzed by LC-tandem MS equipped with a turbo spray electrospray (ESI) interface (Agilent Technologies, Palo Alto, CA and MS/MS, 4000 QTRAP, Applied Biosystems, USA) according to our previous study [6]. Other parameters such as $\mathrm{pH}$, conductivity, and chemical oxygen demand were evaluated according to the Standard Methods for the Examination of Water and Wastewater [32]. In addition to these parameters, sludge production was also analyzed using the gravimetric method. The statistical analysis was performed using the software Minitab 18.1 version (Minitab Inc., USA).

Energy consumed per contaminated pollutant $(E)$ during the EF process could be determined by the following equation [33]:

$$
\mathrm{E}(\mathrm{kWh} / \mathrm{kg} \text { pollutant })=\frac{\mathrm{U} \times \mathrm{I} \times \mathrm{t} \times 1000}{\left(C_{0}-C_{i}\right) 60 \mathrm{~V}} .
$$

The concentration of iron generated in the solution or anode consumption was expressed by the following equation:

$$
\mathrm{m}\left(\mathrm{g}_{\mathrm{Fe}} / \mathrm{m}^{3}\right)=\frac{\mathrm{I} \times \mathrm{t} \times \mathrm{M}}{\mathrm{Z} \times \mathrm{F} \times \mathrm{V}} \times 60 .
$$

where pollutant is TC or TOC, F is Faraday's constant ( $96485 \mathrm{Columb} / \mathrm{mol}), M$ is the molecular weight of iron $(56 \mathrm{~g} / \mathrm{mol}), Z$ is the number of electron transfer (assumed here $\left.Z_{\mathrm{Fe}}=2\right)$, I is the electric current $(\mathrm{A}), \mathrm{U}$ is the voltage $(\mathrm{V})$, $t$ is the electrolysis time ( $\mathrm{min})$, and $\mathrm{V}$ is the treated volume $(L)$. 
TABLE 2: The matrix of the CCD experiment and the corresponding experimental data.

\begin{tabular}{|c|c|c|c|c|c|c|c|}
\hline \multirow{2}{*}{ Run } & \multirow{2}{*}{$\begin{array}{c}\text { Current density } \\
\left(\mathrm{mA} / \mathrm{cm}^{2}\right)\end{array}$} & \multirow{2}{*}{$\begin{array}{c}\mathrm{Fe}^{2+} \text { dosage } \\
(\mathrm{mM})\end{array}$} & \multirow{2}{*}{$\begin{array}{l}\text { Electrolysis time } \\
(\mathrm{min})\end{array}$} & \multicolumn{2}{|c|}{ TC removal (\%) } & \multicolumn{2}{|c|}{ TOC removal (\%) } \\
\hline & & & & Actual & Predicted & Actual & Predicted \\
\hline 1 & 2.22 & 0.20 & 180.0 & 98.9 & 98.74 & 77.10 & 77.22 \\
\hline 2 & 3.33 & 0.10 & 210.0 & 79.6 & 80.10 & 63.60 & 65.52 \\
\hline 3 & 3.33 & 0.30 & 150.0 & 76.3 & 77.21 & 40.40 & 42.67 \\
\hline 4 & 1.11 & 0.30 & 150.0 & 86.2 & 86.59 & 59.80 & 59.32 \\
\hline 5 & 3.33 & 0.10 & 150.0 & 74.2 & 72.27 & 39.34 & 36.38 \\
\hline 6 & 1.11 & 0.10 & 150.0 & 70.64 & 69.22 & 40.26 & 38.64 \\
\hline 7 & 1.11 & 0.10 & 210.0 & 68.4 & 68.37 & 58.70 & 57.88 \\
\hline 8 & 1.11 & 0.30 & 210.0 & 99.1 & 101.91 & 79.10 & 83.51 \\
\hline 9 & 4.09 & 0.20 & 180.0 & 84.7 & 84.06 & 61.40 & 59.54 \\
\hline 10 & 2.22 & 0.20 & 180.0 & 98.7 & 98.74 & 76.10 & 77.22 \\
\hline 11 & 3.33 & 0.30 & 210.0 & 98.9 & 101.21 & 73.70 & 76.77 \\
\hline 12 & 0.35 & 0.20 & 180.0 & 82.7 & 82.09 & 67.30 & 67.11 \\
\hline 13 & 2.22 & 0.20 & 180.0 & 99.2 & 98.74 & 76.40 & 77.22 \\
\hline 14 & 2.22 & 0.20 & 180.0 & 97.6 & 98.74 & 79.10 & 77.22 \\
\hline 15 & 2.22 & 0.20 & 129.5 & 75.1 & 76.74 & 36.80 & 39.15 \\
\hline 16 & 2.22 & 0.03 & 180.0 & 61.31 & 63.45 & 35.04 & 37.81 \\
\hline 17 & 2.22 & 0.37 & 180.0 & 99.2 & 95.81 & 69.47 & 64.65 \\
\hline 18 & 2.22 & 0.20 & 180.0 & 98.5 & 98.74 & 76.00 & 77.22 \\
\hline 19 & 2.22 & 0.20 & 230.5 & 99.1 & 96.21 & 88.40 & 84.00 \\
\hline 20 & 2.22 & 0.20 & 180.0 & 99.3 & 98.74 & 78.26 & 77.22 \\
\hline
\end{tabular}

\section{Results and Discussion}

3.1. Effect of Electrolysis Time and Kinetic Reaction Model on TOC and TC Removal. Figure 2 shows the variation in the electrolysis time on the TC and TOC removal efficiencies. With the increase in the reaction time from 30 to $150 \mathrm{~min}$, the removal efficiency sharply increases, and with the further increase in the electrolysis time, the removal efficiency reaches a plateau. The increase in the rapid and slow removal of TC and TOC with the rise in the electrolysis time can be explained by the reaction between $\bullet \mathrm{OH}$ and TC or TOC in wastewater. At a constant TC or TOC concentration, the increased electrolysis time can accelerate $\bullet \mathrm{OH}$ formation, leading to a rapid reaction with the TC or TOC contaminant. However, under saturated $\mathrm{Fe}^{2+}$ conditions $(0.2 \mathrm{mM})$, fixed - $\mathrm{OH}$ formation inadequate react with the pollutants; therefore, the TC and TOC removal efficiency slowly increase. This trend also can be confirmed in some previous studies $[20,34]$. The kinetics of the TOC and TC removal under fixed conditions $\left(2.22 \mathrm{~mA} / \mathrm{cm}^{2}\right.$ of current density and $0.2 \mathrm{mM}$ of $\mathrm{Fe}^{2+}$ dosage) give a better understanding of the relationship between TOC or TC concentrations and electrolysis times. TOC and TC removal is performed under pseudo-first-order kinetics with $R^{2}$ around 0.923 and 0.993 , respectively, as illustrated in Figure 2. These results are the following ones reported by Teymori et al. [20] that show that the pseudo-first-order reaction is suitable for degradation of Malachite green using the EF process or Covinich et al. [26], who indicated the TOC removal of mixed industrial wastewater using Fenton process followed by pseudo-firstorder kinetics. The high removal efficiency at about $150 \mathrm{~min}$ and the fixed condition of $\mathrm{Fe}^{2+}$ and current density release level of each parameter on CCD design eliminate TC and TOC from RPW.

3.2. Model Fitting and Analysis. The ANOVA results of applying the EF process to the RPW are presented in Table 3, showing significant TC and TOC removal factors according to the CCD design.

Table 3 summarizes the individual and interactive effects and the statistical significance of the test variables on TC and TOC removal. The low $P$ values $(<0.05)$ indicate the significant impact of almost all factors on TC and TOC reduction. These should be included in the final model. These statements are also confirmed through the Pareto chart with 95\% confidence (Figure S1).

Therefore, the model for predicting the removal of TC and TOC using EF is reconstructed to filter out the nonsignificant factors and predicted models, as expressed by the following equations:

$$
\begin{gathered}
Y_{\mathrm{TC}}=180.6 X_{2}+1.513 X_{3}-4.494 X_{1}^{2}-675.5 X_{2}^{2}-0.0048 X_{3}^{2}-28 X_{1} X_{2}+0.651 X_{1} X_{3}+1.348 X_{2} X_{3}-99.5 \\
Y_{\mathrm{TOC}}=8.76 X_{1}+445.1 X_{2}+2.409 X_{3}-3.987 X_{1}^{2}-918.8 X_{2}^{2}-0.0061 X_{3}^{2}-32.4 X_{1} X_{2}-239.6
\end{gathered}
$$

The model F-values of 69.43 and 49.69 for the TC and TOC removal, respectively, indicated that the model is sufficiently significant for the regression analysis between response and variable effects. The fit of the model was verified by determining the regression coefficient $\left(R^{2}\right)$. The

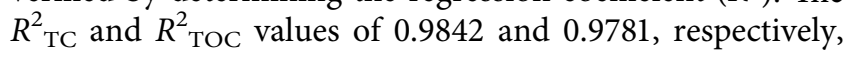




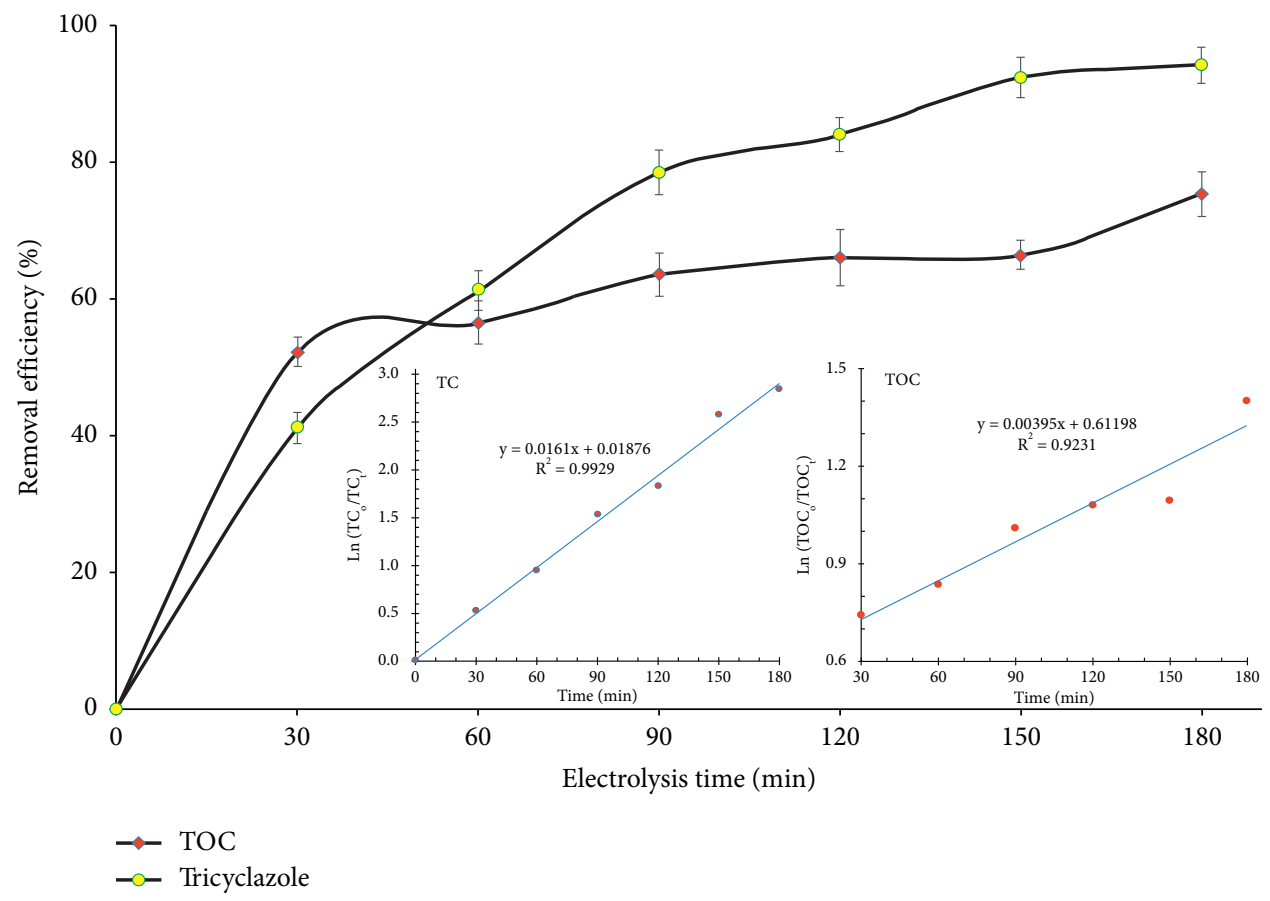

FIGURE 2: Effect of different electrolysis time points and reaction kinetic orders on TC and TOC removal with a current density of $2.22 \mathrm{~mA} /$ $\mathrm{cm}^{2}$ and $0.2 \mathrm{mM} \mathrm{Fe}^{2+}$ dosage.

TABle 3: ANOVA results for the TC and TOC removal from RPW using EF process.

\begin{tabular}{|c|c|c|c|c|c|}
\hline Source & DF & Adj SS & Adj MS & $F$-value & $P$ value \\
\hline \multicolumn{6}{|l|}{ TC removal } \\
\hline Model & 9 & $3,126.26$ & 347.36 & 69.43 & $\leq 0.001$ \\
\hline$X_{1}$ & 1 & 4.71 & 4.71 & 0.94 & 0.355 \\
\hline$X_{2}$ & 1 & $1,263.95$ & $1,263.95$ & 252.65 & $\leq 0.001$ \\
\hline$X_{3}$ & 1 & 457.25 & 457.25 & 91.40 & $\leq 0.001$ \\
\hline$X_{1}^{2}$ & 1 & 441.80 & 441.80 & 88.31 & $\leq 0.001$ \\
\hline$X_{2}^{\frac{1}{2}}$ & 1 & 657.55 & 657.55 & 131.44 & $\leq 0.001$ \\
\hline$X_{3}^{2}$ & 1 & 270.79 & 270.79 & 54.13 & $\leq 0.001$ \\
\hline$X_{1} X_{2}$ & 1 & 77.25 & 77.25 & 15.44 & 0.003 \\
\hline$X_{1} X_{3}$ & 1 & 37.58 & 37.58 & 751 & 0.021 \\
\hline$X_{2} X_{3}$ & 1 & 130.73 & 130.73 & 26.13 & $\leq 0.001$ \\
\hline Residual error & 10 & 50.03 & 5.00 & & \\
\hline Pure error & 5 & 1.90 & 0.38 & & \\
\hline Total & 19 & $3,176.29$ & & & \\
\hline \multicolumn{6}{|l|}{ TOC reduction } \\
\hline Model & 9 & $5,247.22$ & 583.02 & 49.69 & $\leq 0.001$ \\
\hline$X_{1}$ & 1 & 69.20 & 69.20 & 5.90 & 0.036 \\
\hline$X_{2}$ & 1 & 870.03 & 870.03 & 74.15 & $\leq 0.001$ \\
\hline$X_{3}$ & 1 & $2,427.60$ & $2,427.60$ & 206.91 & $\leq 0.001$ \\
\hline$X_{1}^{2}$ & 1 & 347.73 & 347.73 & 29.64 & $\leq 0.001$ \\
\hline$X_{2}^{\frac{1}{2}}$ & 1 & $1,216.69$ & $1,216.69$ & 103.60 & $\leq 0.001$ \\
\hline$X_{3}^{2}$ & 1 & 440.85 & 440.85 & 37.57 & $\leq 0.001$ \\
\hline$X_{1} X_{2}$ & 1 & 103.54 & 103.54 & 8.82 & 0.014 \\
\hline$X_{1} X_{3}$ & 1 & 49.10 & 49.10 & 4.19 & 0.068 \\
\hline$X_{2} X_{3}$ & 1 & 12.25 & 12.25 & 1.04 & 0.331 \\
\hline Residual error & 10 & 117.33 & 11.73 & & \\
\hline Pure error & 5 & 8.02 & 1.60 & & \\
\hline Total & 19 & $5,364.55$ & & & \\
\hline
\end{tabular}

$R_{\text {TC }}^{2}=0.9842, R_{\text {TC_adj }}^{2}=0.9701, R_{\text {TOC }}^{2}=0.9781$, and $R_{\text {TOC_adj }}^{2}=0.9584$. 
indicated that the models cannot explain only the $1.58-2.19 \%$ variation of the mean or that the models exhibit satisfactory adjustment of the quadratic models to the experimental data [35]. Moreover, some investigations revealed that an $R^{2}$ of greater than 0.70 is considered to be suitable for model fitting [36].

Figure 3 illustrates that the TOC removal increased with electrolysis time and varied with current density or $\mathrm{Fe}^{2+}$ dosage. As seen in Figure 3, the TOC removal could be greater than $80 \%$ occurred for conditions current density of 1.11 to $3.50 \mathrm{~mA} / \mathrm{cm}^{2}, \mathrm{Fe}^{2+}$ concentration of $\geq 0.18 \mathrm{mM}$, and electrolysis time of $\geq 190 \mathrm{~min}$.

Figure 4 describes the interactive effect of current density, electrolysis time, and $\mathrm{Fe}^{2+}$ dosage on TC removal efficiency. The best condition for TC removal by EF was electrolysis time of higher $190 \mathrm{~min}$, current density ranged from 2.0 to $3.0 \mathrm{~mA} / \mathrm{cm}^{2}$, and higher $\mathrm{Fe}^{2+}$ dosage of $0.2 \mathrm{mM}$. The increase in TOC removal efficiency as the $\mathrm{Fe}^{2+}$ concentration $\geq 0.2 \mathrm{mM}$ or increase in electrolysis time could be attributed to the generation of an increased number of $\bullet \mathrm{OH}$ through equation (1). The variation of removal efficiencies of TC and TOC in a range of current density is mainly due to the suitable range of current density of the experiment. As the current density increase, the amount of generated $\mathrm{H}_{2} \mathrm{O}_{2}$ and iron ion also increase, thus increasing $\bullet \mathrm{OH}$ formation. However, further increase in the current density could accelerate the production of weak oxidative substances (such as $\mathrm{HO}_{2}{ }^{\bullet}$ or $\mathrm{O}_{2}$ ) according to the following equations [6]:

$$
\begin{gathered}
\mathrm{H}_{2} \mathrm{O}_{2}+\mathrm{OH} \longrightarrow \mathrm{HO}_{2}^{\circ}+\mathrm{H}_{2} \mathrm{O} \\
\mathrm{HO}_{2}+\mathrm{OH} \longrightarrow \mathrm{H}_{2} \mathrm{O}+\mathrm{O}_{2}
\end{gathered}
$$

These increase and variations of trends in electrolysis time and current density are consistent with the previous study of Zhang et al. [37]; they stated that the decomposition of $5,000 \mathrm{mg} / \mathrm{L}$ of COD from landfill leachate to around $2,500 \mathrm{mg} / \mathrm{L}$ only within $30 \mathrm{~min}$ and obtained $1,000 \mathrm{mg} / \mathrm{L}$ around $75 \mathrm{~min}$.

From the model, the optimization of the EF treatment was reached with the highest removal efficiency of both TC and TOC; the optimization indicated that at $2.2 \mathrm{~mA} / \mathrm{cm}^{2}$ of current density, $0.25 \mathrm{mM}$ of $\mathrm{Fe}^{2+}$ concentration, and $217 \mathrm{~min}$ of electrolysis time, the TOC and TC removal reached $87.76 \%$ and $104.8 \%$ with the desirability function value of 0.901 (Figure 5). Two additional experiments were then performed to verify the optimum results. The average TOC and TC removal value obtained through the experiment was $84.24 \%$ and $99.23 \%$, respectively, which agreed well with the predicted response value.

In the case of individual optimization for TC and TOC, the best conditions should be $2.2 \mathrm{~mA} / \mathrm{cm}^{2}$ of current density, $0.2 \mathrm{mM}$ of $\mathrm{Fe}^{2+}$ concentration and $188 \mathrm{~min}$ of electrolysis time or $2.2 \mathrm{~mA} / \mathrm{cm}^{2}$ of current density, $0.25 \mathrm{mM}$ of $\mathrm{Fe}^{2+}$ concentration, and $217 \mathrm{~min}$ of electrolysis time for elimination of $100 \%$ TC and $87.8 \%$ TOC as depicted in Figure 6. Two confirmation trials in optimization of TC reach $99.6 \%$, which is better the optimization value of both TC and TOC and closer than the predicted value. The value was chosen for the cost evaluation.

3.3. Toxicity Evaluation. The toxicity of treated real pesticides at optimum condition for both TC and TOC was investigated using D. magna; the survival of D. magna in the controls without pesticide wastewater was $100 \%$. According to OECD guidelines, this high control survival meets the requirement for the toxicity test [28]. The lethal concentration (LC) values of the treated pesticide wastewater (TPW) by EB against the microcrustacean D. magna at different time intervals are listed in Table 4 . The results demonstrated that the TPW generated moderate toxic effects on D. magna, with $\mathrm{LC}_{50}$ values of $3.12 \%, 2.05 \%, 1.81 \%$, and $1.36 \%$ at $24 \mathrm{~h}, 48 \mathrm{~h}, 72 \mathrm{~h}$, and $96 \mathrm{~h}$, respectively. These toxicity results are lower than our previous pesticide wastewater on D. magna [6]. However, the pesticide wastewater treatment with this condition still generates toxic effects on D. magna. Probably, the treated pesticide wastewater contained unknown or other toxic compounds that contributed to toxic effects on D. magna. Further study on the chemical composition and toxic effects of this treated wastewater on other aquatic organisms is recommended. The method could require more treatment steps to reach the standard for release to the environment.

3.4. Economic Aspect. One of the most contributions to EF cost is energy consumption, which significantly increases by current density or electrolysis time [18]. The energy consumption for EF treatment was described in equation (4). Given the Vietnamese market in May 2021, the electrical energy price is $0.06 \$ / \mathrm{kWh}$, and chemical prices are $\mathrm{H}_{2} \mathrm{SO}_{4} 0.25 \$ / \mathrm{kg}, \mathrm{FeSO}_{4} 0.17 \$ / \mathrm{kg}, \mathrm{Na}_{2} \mathrm{SO}_{4} 0.35 \$ / \mathrm{kg}$, and electrode anode $0.33 \$ / \mathrm{kg}$ (iron). The optimal cost associated with treatment conditions is summarized in Table S1. As shown in Table S1, the operating costs to treat 99.6\% TC and 84.2\% TOC in RPW using EF were 3.019 $\$ / \mathrm{kg}$ TOC and $121.392 \$ / \mathrm{kg}$ TC, corresponding to 3.916 $\$ / \mathrm{m}^{3}$ and $2.962 \$ / \mathrm{m}^{3}$ containing $1,297 \mathrm{mg} / \mathrm{L}$ TOC and $24.4 \mathrm{mg} / \mathrm{L}$ TC, respectively. The high energy consumption in TC removal was mainly due to the low concentration of TC in RPW, which required many chemicals or energy costs for treatment. While the energy consumption to remove $1 \mathrm{~kg}$ of TOC in real wastewater is far below the energy consumption of EF reported from previous studies [38-42]. Flox et al. [39] indicated an energy consumption cost of around $2.872 \$ / \mathrm{kg}$ TOC to eliminate $97 \%$ TOC of Mecoprop solution using boron-doped diamond (BDD)/ stainless steel electrodes. Guinea et al. [42] applied BDD anode to degrade over $97 \%$ TOC of enrofloxacin solution with very high energy consumption (14.76 \$/kg TOC). A summary list of different contaminant sources degradation by EF along with their treatment efficiency is presented in Table 5. The results indicated that the EF process was suitable for wastewater treatment in a future largescale application. 


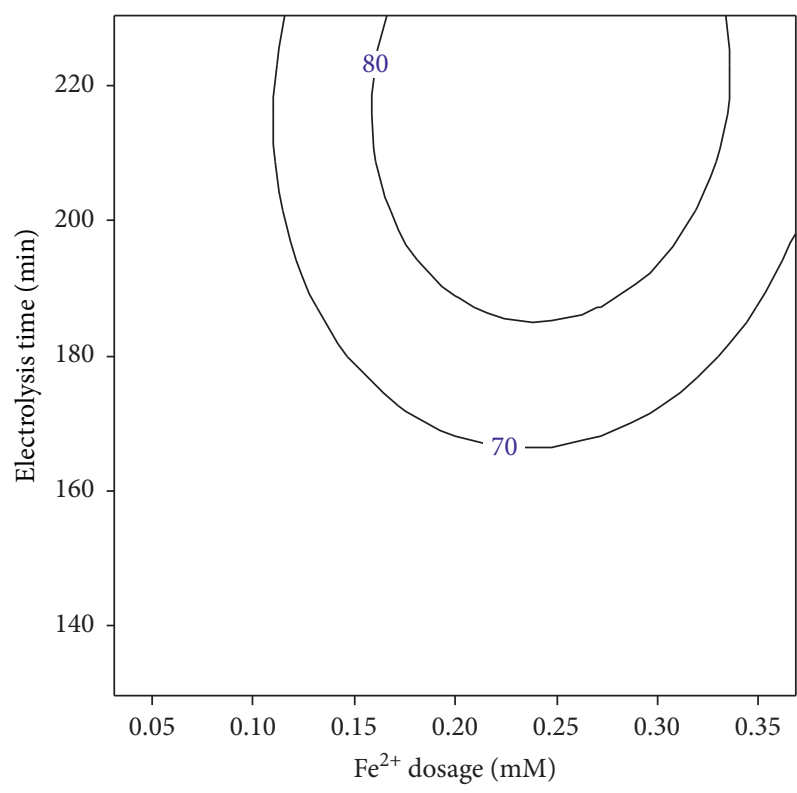

(a)

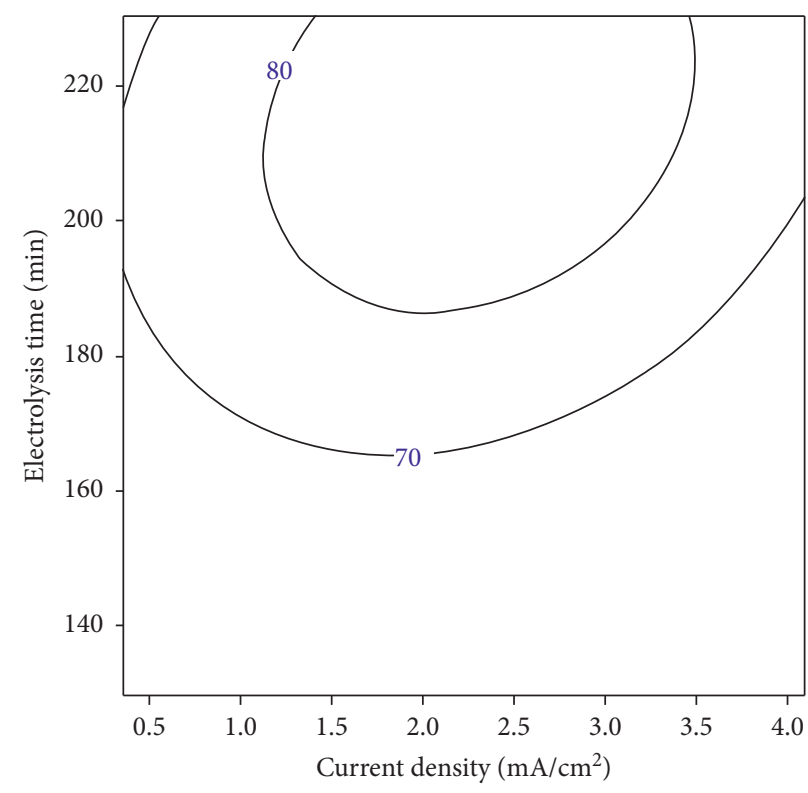

(b)

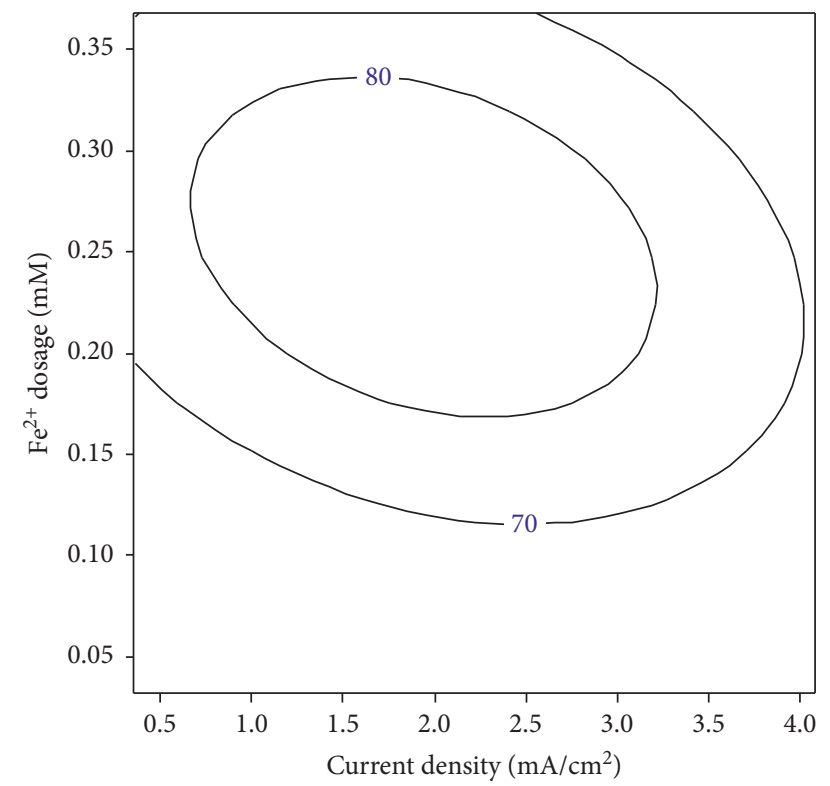

(c)

Figure 3: Respond contour plot of TOC removal at fixed condition: (a) current density of $2.5 \mathrm{~mA} / \mathrm{cm}^{2}$, (b) $\mathrm{Fe}^{2+}$ dosage of $0.2 \mathrm{mM}$, and (c) electrolysis time of $200 \mathrm{~min}$. 


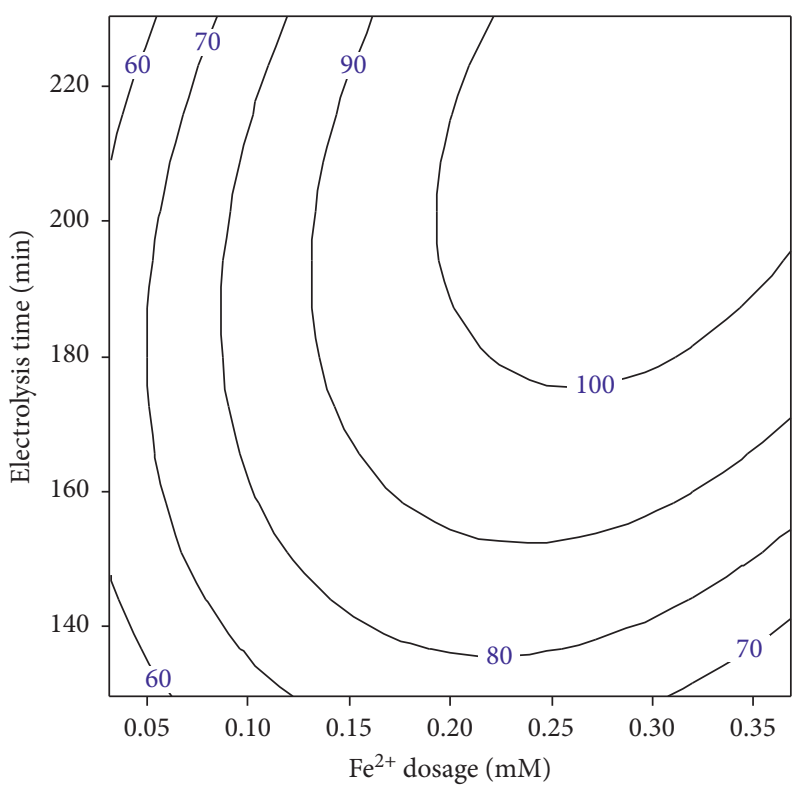

(a)

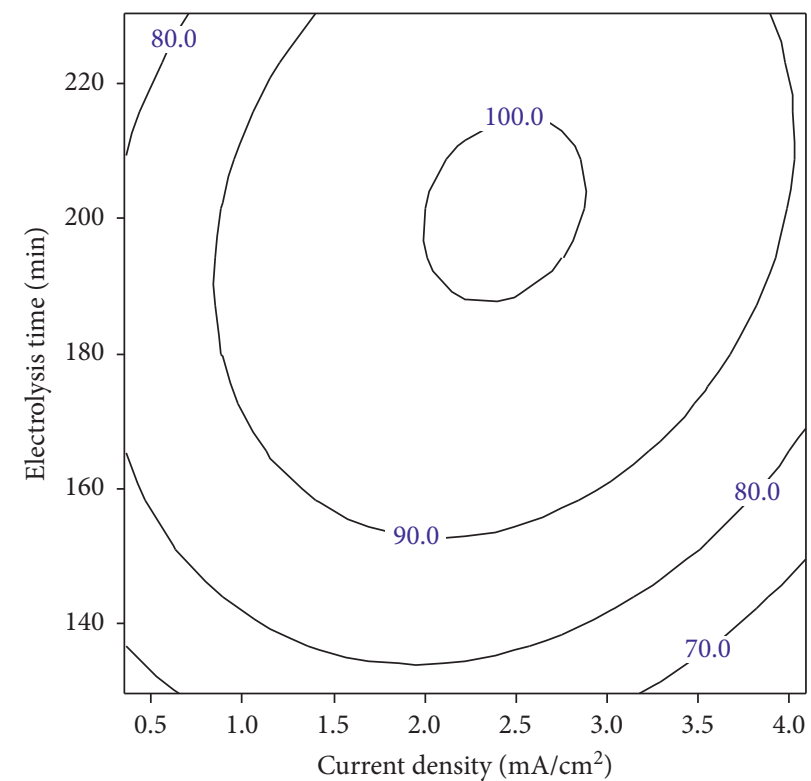

(b)

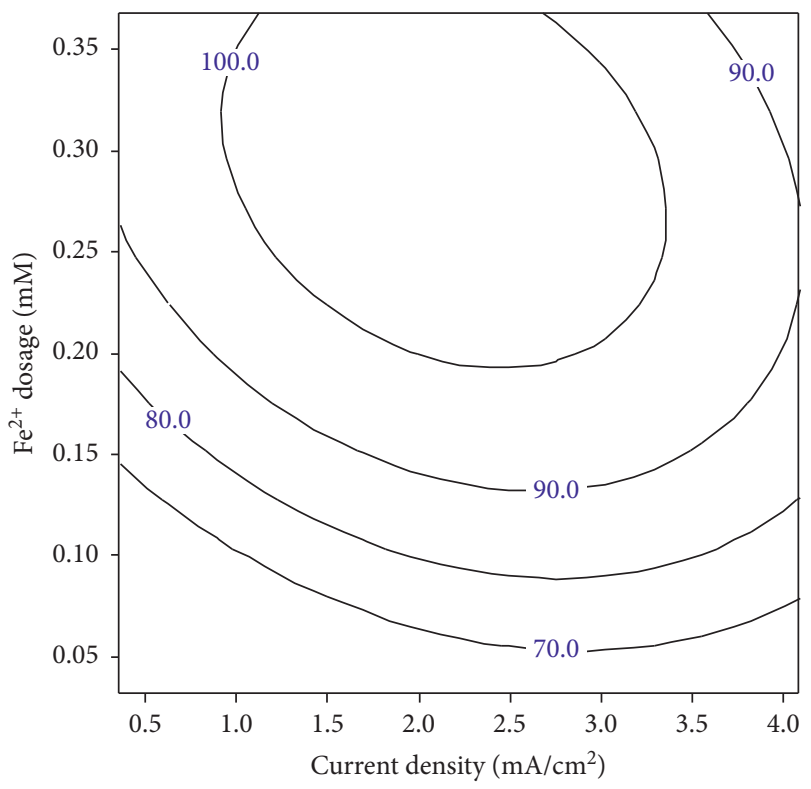

(c)

Figure 4: Respond contour plot of TC removal at fixed condition: (a) current density of $2.5 \mathrm{~mA} / \mathrm{cm}^{2}$, (b) Fe $\mathrm{Fe}^{2+}$ dosage of $0.2 \mathrm{mM}$, and (c) electrolysis time of $200 \mathrm{~min}$. 


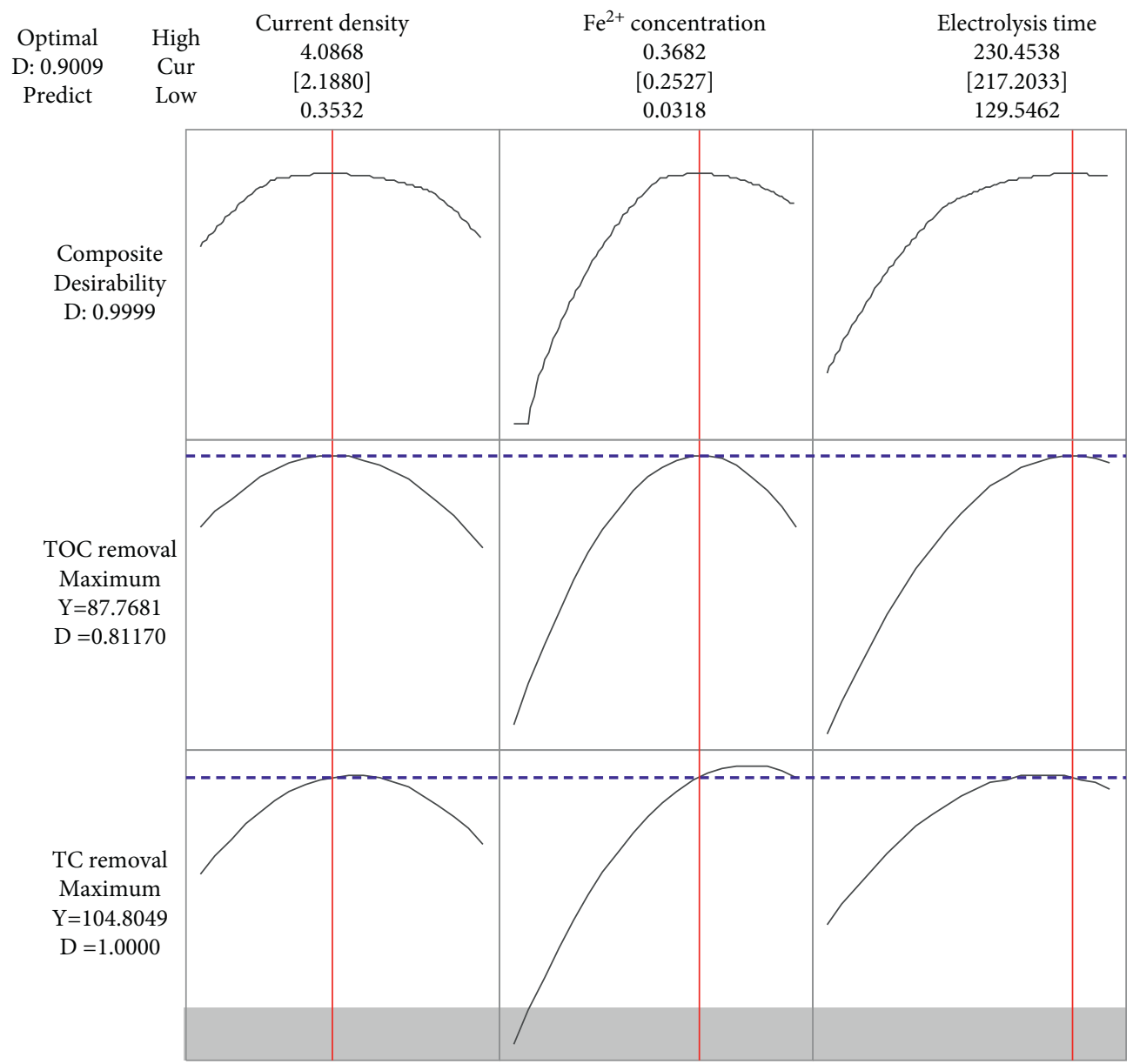

Figure 5: Response optimization plot of maximum both TOC and TC removal efficiency.

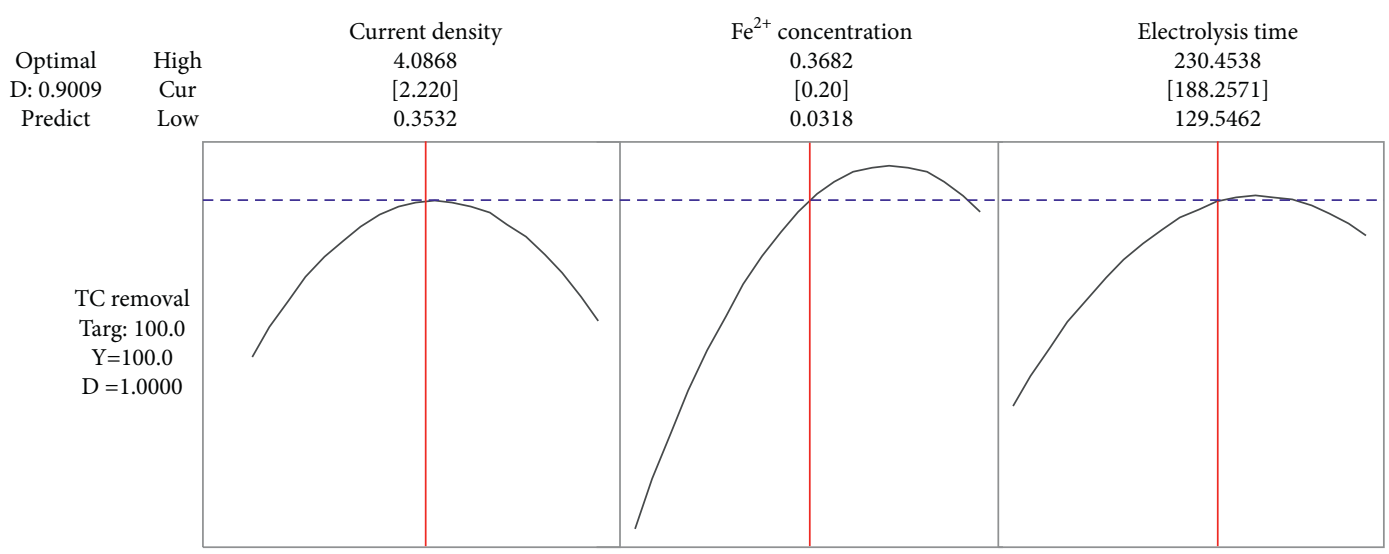

(a)

Figure 6: Continued. 


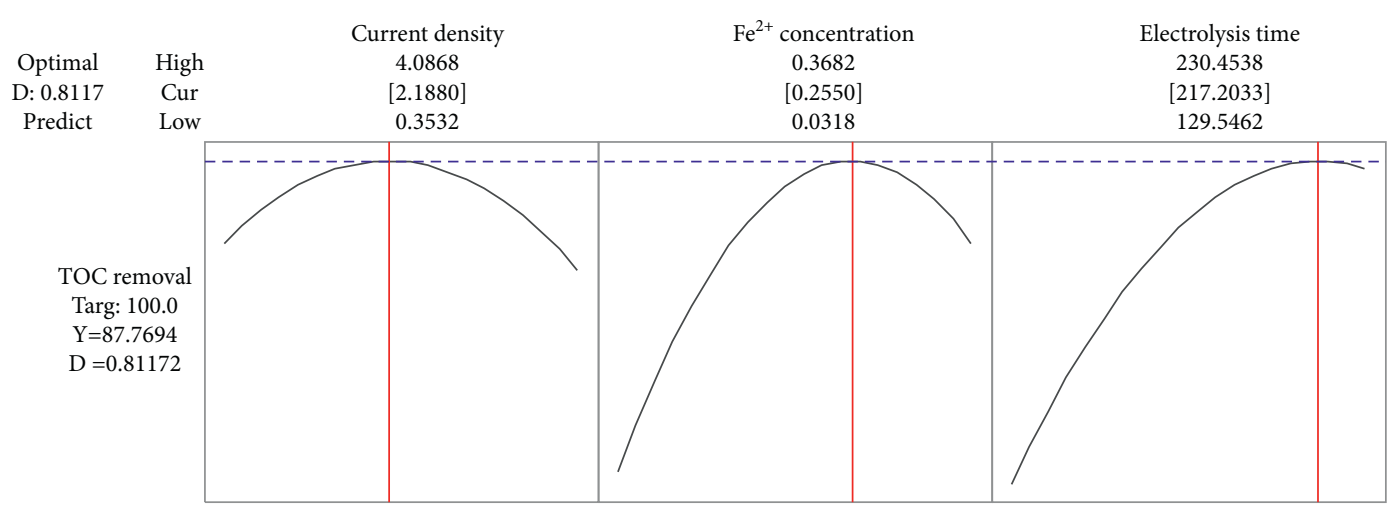

(b)

FIGURE 6: Response optimization plot of individual: (a) TC and (b) TOC removal efficiency in RWP using EF.

TABLE 4: Lethal dose $\mathrm{LC}_{50}$ of the TPW samples on $D$. magna.

\begin{tabular}{lcccrr}
\hline Chemical & Time $(\mathrm{h})$ & $24 \mathrm{~h}$ & $48 \mathrm{~h}$ & $72 \mathrm{~h}$ & $96 \mathrm{~h}$ \\
\hline & $\mathrm{LC}_{10}$ & 1.34 & 0.98 & 0.69 & 1.81 \\
TPW (\%) & $\mathrm{LC}_{50}$ & 3.12 & 2.05 & 1.36 \\
& $\mathrm{LC}_{90}$ & 3.54 & 2.24 & 1.92 & 1.54 \\
\hline
\end{tabular}

TABLE 5: Energy consumption per unit TOC mass for the degradation of several organic pollutant solutions by the EF process.

\begin{tabular}{|c|c|c|c|c|c|}
\hline Compounds & Cell & Conditions & $\begin{array}{c}\text { Removal } \\
\text { efficiency }(\%)\end{array}$ & $\begin{array}{c}E(\mathrm{kWh} / \\
\mathrm{kg})\end{array}$ & Ref. \\
\hline Mecoprop & $\mathrm{BDD} /$ stainless steel & $\begin{array}{c}643 \mathrm{mg} / \mathrm{L} \text { pesticide in } 0.5 \mathrm{M} \mathrm{Na}_{2} \mathrm{SO}_{4}, \mathrm{pH} 3.0,0.5 \mathrm{mM} \\
\mathrm{Fe}^{2+}, 50 \mathrm{~mA} / \mathrm{cm}^{2} \text {, and } 40^{\circ} \mathrm{C} \text { for } 540 \mathrm{~min}\end{array}$ & 97 (TOC) & 47.87 & [39] \\
\hline Cresol & $\begin{array}{l}\text { BDD/gas diffusion electrode } \\
\text { (GDE) }\end{array}$ & $\begin{array}{c}128 \mathrm{mg} / \mathrm{L} \text { substrate in } 0.05 \mathrm{M} \mathrm{Na}_{2} \mathrm{SO}_{4}, \mathrm{pH} 3.0,1 \mathrm{mM} \\
\mathrm{Fe}^{2+}, 1^{\circ} \mathrm{A} \text {, and } 35^{\circ} \mathrm{C} \text { for } 180 \mathrm{~min}\end{array}$ & 98 (TOC) & 155 & {$[40]$} \\
\hline $\begin{array}{l}\text { Diuron, } \\
\text { glyphosate }\end{array}$ & $\begin{array}{l}\text { Dimensionally stable } \\
\text { electrode (DSA)/carbon felt }\end{array}$ & 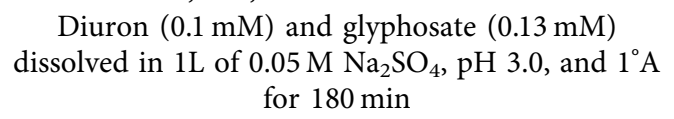 & 33.78 (TOC) & 850 & [38] \\
\hline Acid yellow 36 & $\mathrm{BDD} / \mathrm{GDE}$ & $\begin{array}{c}108 \mathrm{mg} / \mathrm{L} \text { dye in } 0.05 \mathrm{M} \mathrm{Na}_{2} \mathrm{SO}_{4}, \mathrm{pH} 3.0,0,5 \mathrm{mM} \\
\mathrm{Fe}^{2+}, 50 \mathrm{~mA} / \mathrm{cm}^{2} \text {, and } 40^{\circ} \mathrm{C} \text { for } 540 \mathrm{~min}\end{array}$ & 95 (TOC) & 130 & {$[41]$} \\
\hline Enrofloxacin & $\mathrm{Pt} / \mathrm{BDD}$ & $\begin{array}{c}158 \mathrm{mg} / \mathrm{L} \mathrm{drug} \mathrm{in} 0.05 \mathrm{M} \mathrm{Na}_{2} \mathrm{SO}_{4}, 0.2 \mathrm{mM} \mathrm{Fe}{ }^{2+}, \mathrm{pH} \\
3,1^{\circ} \mathrm{A} \text {, and } 35^{\circ} \mathrm{C} \text { for } 300 \mathrm{~min}\end{array}$ & 97 (TOC) & 246 & {$[42]$} \\
\hline Tricyclazole & Carbon plate/stainless steel & $\begin{array}{l}1297 \mathrm{mg} / \mathrm{L} \text { pesticide in } 990 \mathrm{mg} / \mathrm{L} \mathrm{Na}_{2} \mathrm{SO}_{4}, \mathrm{pH} 3.0 \text {, } \\
0.25 \mathrm{mM} \mathrm{Fe}{ }^{2+}, 2.22 \mathrm{~mA} / \mathrm{cm}^{2} \text {, and } 25^{\circ} \mathrm{C} \text { for } 217 \mathrm{~min}\end{array}$ & $\begin{array}{c}99.6(\mathrm{TC}) \\
84.2(\mathrm{TOC})\end{array}$ & $\begin{array}{l}121.4 \\
3.02\end{array}$ & $\begin{array}{l}\text { This } \\
\text { study }\end{array}$ \\
\hline
\end{tabular}

\section{Conclusions}

This study employed the electro-Fenton process with stainless steel and carbon fiber as electrodes to treat tricyclazole (TC) and TOC in real pesticide production wastewater (RPW). The removal of TC and TOC was obeyed pseudo-first-order kinetic with $R^{2}$ of 0.993 and 0.923 , respectively. The central composite design (CCD) with three factors was successfully applied to develop a mathematical model predicting TC and TOC removal. The $R^{2}$ TC $=0.9842$ and $R^{2}$ TOC $=0.9781$ for the obtained quadratic model indicate a high correlation between observed and predicted values by the mathematical model. At optimum values of variables (current density of $2.2 \mathrm{~mA} / \mathrm{cm}^{2}, \mathrm{Fe}^{2+}$ dosage of $0.2 \mathrm{mM}$, and electrolysis time of $217 \mathrm{~min}$ ), most of the TC (99.6\%) and TOC (84.2\%) was eliminated. The acute toxicity of this contaminant at optimization conditions still generated toxic effects on D. magna. Besides, the operation cost per mass unit of EF at individual optimization was around $3.019 \$ / \mathrm{kg}$ TOC and $121.392 \$ / \mathrm{kg}$ TC also represented the practical technique in wastewater treatment.

\section{Data Availability}

All data are included within the article.

\section{Conflicts of Interest}

The authors declare that they have no conflicts of interest.

\section{Acknowledgments}

This research was funded by Vietnam National University Ho Chi Minh City (VNU-HCM) under grant number C2019-24-01. 


\section{Supplementary Materials}

Table S1. Operation cost for the mineralization of wastewater containing pesticide compounds for EF treatments. Figure S1. Pareto chart for the analysis of the experimental data obtained to remove: (a) TC and (b) TOC from the RPW by $\mathrm{EF}$ technique with $95 \%$ confidence. (Supplementary Materials)

\section{References}

[1] Statista, "Agriculture in Vietnam-statistics \& facts," Statista Research Department, vol. 2021, 2021.

[2] J.-Y. Liao, C. Fan, Y.-Z. Huang, and K. J.-C. Pei, "Distribution of residual agricultural pesticides and their impact assessment on the survival of an endangered species," Journal of Hazardous Materials, vol. 389, Article ID 121871, 2020.

[3] S. Cui, R. Hough, K. Yates et al., "Effects of season and sediment-water exchange processes on the partitioning of pesticides in the catchment environment: implications for pesticides monitoring," The Science of the Total Environment, vol. 698, Article ID 134228, 2020.

[4] T. Wang, M. Zhong, M. Lu et al., "Occurrence, spatiotemporal distribution, and risk assessment of current-use pesticides in surface water: a case study near Taihu Lake, China," The Science of the Total Environment, vol. 782, Article ID 146826, 2021.

[5] H. Hamsan, Y. B. Ho, S. Z. Zaidon, Z. Hashim, N. Saari, and A. Karami, "Occurrence of commonly used pesticides in personal air samples and their associated health risk among paddy farmers," The Science of the Total Environment, vol. 603-604, pp. 381-389, 2017.

[6] N. N. Duy, T. N. Hieu, T. P. Luu et al., "Degradation of tricyclazole from aqueous solution and real wastewater by electron-beam irradiation," Environmental Technology \& Innovation, vol. 21, Article ID 101315, 2021.

[7] I. Werner, L. A. Deanovic, D. E. Hinton et al., "Toxicity of stormwater runoff after dormant spray application of diazinon and esfenvalerate (asana) in a French prune orchard, glenn county, California, USA," Bulletin of Environmental Contamination and Toxicology, vol. 68, no. 1, pp. 29-36, 2002.

[8] H. Wu, J. Shen, X. Jiang et al., "Bioaugmentation potential of a newly isolated strain Sphingomonas sp. NJUST37 for the treatment of wastewater containing highly toxic and recalcitrant tricyclazole," Bioresource Technology, vol. 264, pp. 98-105, 2018.

[9] L. Feng, E. D. van Hullebusch, M. A. Rodrigo, G. Esposito, and M. A. Oturan, "Removal of residual anti-inflammatory and analgesic pharmaceuticals from aqueous systems by electrochemical advanced oxidation processes. A review," Chemical Engineering Journal, vol. 228, pp. 944-964, 2013.

[10] G. Briceño, M. S. Fuentes, J. M. Saez, M. C. Diez, and C. S. Benimeli, "Streptomyces genus as biotechnological tool for pesticide degradation in polluted systems," Critical Reviews in Environmental Science and Technology, vol. 48, no. 10-12, pp. 773-805, 2018.

[11] S. Azarkan, A. Peña, K. Draoui, and C. I. Sainz-Díaz, "Adsorption of two fungicides on natural clays of Morocco," Applied Clay Science, vol. 123, pp. 37-46, 2016.

[12] Y. Kiso, Y. Sugiura, T. Kitao, and K. Nishimura, "Effects of hydrophobicity and molecular size on rejection of aromatic pesticides with nanofiltration membranes," Journal of Membrane Science, vol. 192, no. 1-2, pp. 1-10, 2001.
[13] I. Oller, S. Malato, and J. A. Sánchez-Pérez, "Combination of advanced oxidation processes and biological treatments for wastewater decontamination-a review," The Science of the Total Environment, vol. 409, no. 20, pp. 4141-4166, 2011.

[14] O. Ganzenko, C. Trellu, N. Oturan et al., "Electro-Fenton treatment of a complex pharmaceutical mixture: mineralization efficiency and biodegradability enhancement," Chemosphere, vol. 253, Article ID 126659, 2020.

[15] P. T. T. Nguyen, H. T. Nguyen, U. N. P. Tran, and H. Manh Bui, "Removal of antibiotics from real hospital wastewater by cold plasma technique," Journal of Chemistry, vol. 2021, Article ID 9981738, 13 pages, 2021.

[16] N. N. Duy, T. N. Hieu, T. P. Luu et al., "Removal of leucomalachite green in an aqueous solution by the electron beam process," Journal of Water Process Engineering, vol. 40, Article ID 101781, 2021.

[17] E. Brillas and C. A. Martínez-Huitle, "Decontamination of wastewaters containing synthetic organic dyes by electrochemical methods. An updated review," Applied Catalysis B: Environmental, vol. 166-167, pp. 603-643, 2015.

[18] M. B. Ha and X. B. Thanh, Degradation of Complex Organic Pollutants in Wastewater by Homogeneous Electro-Fenton in: Water and Wastewater Treatment Technologies, pp. 145-166, Springer, Berlin, Germany, 2019.

[19] C. T. Benatti, A. C. S. da Costa, and C. R. G. Tavares, "Characterization of solids originating from the Fenton's process," Journal of Hazardous Materials, vol. 163, no. 2-3, pp. 1246-1253, 2009.

[20] M. Teymori, H. Khorsandi, A. A. Aghapour, S. J. Jafari, and R. Maleki, "Electro-Fenton method for the removal of malachite green: effect of operational parameters," Applied Water Science, vol. 10, pp. 1-14, 2020.

[21] Ö. Gökkuş, N. Yıldız, A. S. Koparal, and Y. Yıldız, "Evaluation of the effect of oxygen on electro-Fenton treatment performance for real textile wastewater using the Taguchi approach," International journal of Environmental Science and Technology, vol. 15, no. 2, pp. 449-460, 2018.

[22] X. Zhou, Z. Hou, L. Lv, J. Song, and Z. Yin, "Electro-Fenton with peroxi-coagulation as a feasible pre-treatment for highstrength refractory coke plant wastewater: parameters optimization, removal behavior and kinetics analysis," Chemosphere, vol. 238, Article ID 124649, 2020.

[23] C. M. Dominguez, N. Oturan, A. Romero, A. Santos, and M. A. Oturan, "Optimization of electro-Fenton process for effective degradation of organochlorine pesticide lindane," Catalysis Today, vol. 313, pp. 196-202, 2018.

[24] N. T. Hoang and R. Holze, "Degradation of pesticide Cartap in Padan 95SP by combined advanced oxidation and electrofenton process," Journal of Solid State Electrochemistry, vol. 25, no. 1, pp. 73-84, 2021.

[25] A. Da Pozzo, C. Merli, I. Sirés, J. A. Garrido, R. M. Rodríguez, and E. Brillas, "Removal of the herbicide amitrole from water by anodic oxidation and electro-Fenton," Environmental Chemistry Letters, vol. 3, no. 1, pp. 7-11, 2005.

[26] L. Covinich, F. Felissia, P. Massa, R. Fenoglio, and M. C. Area, "Kinetic modeling of a heterogeneous Fenton-type oxidative treatment of complex industrial effluent," International Journal of Integrated Care, vol. 9, no. 3, pp. 215-229, 2018.

[27] S. O. Ganiyu, C. A. Martínez-Huitle, and M. A. Oturan, "Electrochemical advanced oxidation processes for wastewater treatment: advances in formation and detection of reactive species and mechanisms," Current Opinion in Electrochemistry, vol. 27, Article ID 100678, 2021. 
[28] OECD, Daphnia sp. Acute Immobilization Test: OECD Guideline for Testing of Chemicals, Organization for the Economical Cooperation and Development, Paris, France, 2004.

[29] I. Römer, A. J. Gavin, T. A. White et al., "The critical importance of defined media conditions in Daphnia magna nanotoxicity studies," Toxicology Letters, vol. 223, no. 1, pp. 103-108, 2013.

[30] L. Zhou, Z. Hu, C. Zhang, Z. Bi, T. Jin, and M. Zhou, "Electrogeneration of hydrogen peroxide for electro-Fenton system by oxygen reduction using chemically modified graphite felt cathode," Separation and Purification Technology, vol. 111, pp. 131-136, 2013.

[31] M. B. Ha, "Optimization of electrocoagulation of instant coffee production wastewater using the response surface methodology," Polish Journal of Chemical Technology, vol. 19, pp. 67-71, 2017.

[32] APHA, Standard Methods for the Examination of Water and Wastewater, American Public Health Association (APHA), Washington, DC, USA, 2005.

[33] L. Tirado, Ö. Gökkuş, E. Brillas, and I. Sirés, "Treatment of cheese whey wastewater by combined electrochemical processes," Journal of Applied Electrochemistry, vol. 48, no. 12, pp. 1307-1319, 2018.

[34] M. Malakootian and A. Moridi, "Efficiency of electro-Fenton process in removing Acid Red 18 dye from aqueous solutions," Process Safety and Environmental Protection, vol. 111, pp. 138-147, 2017.

[35] D. C. Montgomery, Design and Analysis of Experiments, John Wiley \& Sons, Inc., Hoboken, NJ, USA, 2013.

[36] D. Granato and M. L. Masson, "Instrumental color and sensory acceptance of soy-based emulsions: a response surface approach," Ciência e Tecnologia de Alimentos, vol. 30, no. 4, pp. 1090-1096, 2010.

[37] H. Zhang, D. Zhang, and J. Zhou, "Removal of COD from landfill leachate by electro-Fenton method," Journal of Hazardous Materials, vol. 135, no. 1-3, pp. 106-111, 2006.

[38] M. P. Rosa Barbosa, N. S. Lima, D. B. de Matos et al., "Degradation of pesticide mixture by electro-Fenton in filterpress reactor," Journal of Water Process Engineering, vol. 25, pp. 222-235, 2018.

[39] C. Flox, P. L. Cabot, F. Centellas et al., "Electrochemical combustion of herbicide mecoprop in aqueous medium using a flow reactor with a boron-doped diamond anode," Chemosphere, vol. 64, no. 6, pp. 892-902, 2006.

[40] C. Flox, P. Cabot, F. Centellas et al., "Solar photoelectroFenton degradation of cresols using a flow reactor with a boron-doped diamond anode," Applied Catalysis B: Environmental, vol. 75, no. 1-2, pp. 17-28, 2007.

[41] E. J. Ruiz, C. Arias, E. Brillas, A. Hernández-Ramírez, and J. M. Peralta-Hernández, "Mineralization of Acid Yellow $36 a z o$ dye by electro-Fenton and solar photoelectro-Fenton processes with a boron-doped diamond anode," Chemosphere, vol. 82, no. 4, pp. 495-501, 2011.

[42] E. Guinea, J. A. Garrido, R. M. Rodríguez et al., "Degradation of the fluoroquinolone enrofloxacin by electrochemical advanced oxidation processes based on hydrogen peroxide electrogeneration," Electrochimica Acta, vol. 55, no. 6, pp. 2101-2115, 2010. 